\title{
The Impact of Foreign Direct Investment (FDI) on Economic Growth (EG): Evidence from Djibouti
}

\begin{abstract}
Nashwa Maguid Hayel
School of International Trade and Economics, Jiangxi University of Finance and Economics, China
\end{abstract}

Bouchra Es. Saiydy

School of International Trade and Economics, Jiangxi University of Finance and Economics, China

Received: October 22, 2021 Accepted: October 30, $2021 \quad$ Published: November 1, 2021

doi: 10.5296/ire.v9i2.19134 URL: https://doi.org/10.5296/ire.v9i2.19134

\begin{abstract}
The achievement of EG and development is considered the core objective for both Developing Countires (DCs) and Least Developed Countries (LDCs), so countries try to get adequate funding to achieve this goal through optimal macroeconomic policies and different strategies. Countries prefer other mechanisms with less burden and cost to achieve economic growth, such as FDI flows. International development-oriented institutions such as WB and IMF recommend and consider FDI flows as the most important factors of the modern technology transfer, management, and know-how, which is necessarily needed in the local investment projects in poor countries, Therefore FDI represents optimal external sources of growth.

The objective of this study is to explain the impact of FDI on the EG of Djibouti. To achieve this objective the study used a secondary annual time series data for the period 1985-2019 by the method of Ordinary Least Square (OLS).

The study results showed that FDI in the case of Djibouti tends to be statistically insignificant effects on Djibouti's EG; on the other hand other factors such as the Human Development Index (HDI) and Gross Fixed Capital Formation (GFCF), Trade Openness (TOP) shows significant effects on the Gross Domestic Product (GDP). Finally, the Consumer Price Index (CPI) has no significance in the EG of Djibouti.
\end{abstract}

The findings provide critical information to Djibouti policy decision-makers to make an 
informed decision with regard to attracting investment and policies in encouraging foreign investors to invest in the country.

Keywords: Foreign direct investment, Economic growth, Djibouti, Empirical analysis

\section{Introduction}

The commitment of FDI to the Economic growth of host nations couldn't possibly be more significant. Most nations exceptionally looked for FDI in light of the fact that it was viewed as a significant catalyst for Economic growth in non-industrial nations. As indicated by (Osu Antwi et al., 2013), the capacity of FDI to meet two significant obstructions; Specifically, the absence of financial assets, innovation, and abilities have made it the focal point of strategy producers in low-pay nations specifically. The greater part of the arising African nations experience the ill effects of a deficiency of capital and consequently the requirement for FDI. Foreign Direct Investments (FDI) can also be considered as cross-line financial ventures between organizations, having a place with a similar multinational gathering (Jannick et al., 2019).

The effect of FDI on monetary development has been a subject of significant discussion in numerous African nations. Since the mid-1990s, FDI has turned into the main wellspring foreign capital for developing market economies (Hussain \& Haq, 2016). In any case, not all FDI puts capital at the assistance of efficiency gains. (Jannick et al., 2019) It creates the impression that the accomplishment of FDI targets has been restricted in Africa. Indeed, FDI streams in Africa have as of late kept on declining, coming to $\$ 42$ billion, down $21 \%$ from 2016 (UNCTAD, 2018). The relationship FDI and EG has attracted great interest from academics and developing country governments (Dinh, DH Vo, TC Nguyen, 2019).

Since Egypt, one of its main concerns has been to prioritize policies related to attracting FDI during the process of geographical representation and development in these countries (Nguyen et al., 2019). In this area of globalization, where economic, trade and technological barriers are disappearing, developing countries focus on FDI due to its positive effects (Demirsel et al., 2014). Although each country has its own characteristics and strengths that must be taken advantage of when working towards Egypt, foreign direct investment still plays an essential role among the main factors that directly affect growth; FDI is key to global economic integration, providing financial stability, advancing Egypt, and improving social welfare (Borensztein et al., 1998; Nguyen et al., 2019).

In general, FDI not only increases the supply of capital, but can, under appropriate host country policies, facilitate technology, and technology transfer contributes to human capital formation that can enhance the prospects for visual representation. In other words, FDI can facilitate the EG process through direct and indirect channels (Osano, 2016).

The connection among FDI and EG intriguing has been intriguing for a very long time; there is impressive contention in the writing about the effect of remote direct venture on EG. Few researchers consider the relationship between FDI and EG to be a strong positive one (Sridevi, 2015). On the other hand, some researchers suggest that FDI can have a negative impact on the EG. (Hermes, 2014). 


\subsection{Purpose of the Study}

The objective of this study is to explain the impact of FDI on the EG of Djibouti. The study also aims at measuring the impact of FDI on economic growth of Djibouti by building a standard model that helps analyze this relationship, it Provides recommendations to the Government of Djibouti decision-makers to help them take the appropriate steps and decisions to correct the mechanism of action taken in dealing with FDI, as well as its role in achieving targeted EG.

\subsection{Significance of the Study}

The importance of FDI and the EG of the host country occupy a prominent place in the priorities of economic decision-makers in all countries when formulating EG plans, where studies and research in this area are particularly important.

There are many studies and research in this area, whether in a group of countries or in a country. But it's different when it comes to the Republic of Djibouti (RoD) being one of the LDCs in the world, there is growing interest from successive governments to achieve rapid and sustainable EG by attracting more FDI. There are no studies on this subject in the State of Djibouti so this study will shed light on them and know the impact of foreign investment in Djibouti growth, and this study will serve future studies; I will provide new evidence in this area.

\subsection{FDI in Djibouti}

Countries have grown and demonstrated the importance the previous decade and are currently in excess of a third of worldwide streams. A few developing economies have drawn in foreign investment economies, including China, India, Brazil, the Republic of Korea, Malaysia, South Africa, Mexico, Hong Kong, and Singapore. This load of nations has worked on their portion of the progression of FDI, as per different nations, and numerous nations have changed their constitution (law) identified with FDI on the grounds that they needed to draw in global organizations that need to contribute and profit from the assets from these nations. To fortify Macroeconomic strength, charge, change and capital record progression, (Mohamed, 2017).

Djibouti is a member of a few provincial associations, for example, the Common Market for Eastern and Southern Africa (COMESA), made out the 19 states assembled under a typical market, the Intergovernmental Expert on Advancement (IGAD) and a part association. World Trade Organization (WTO) since May 31, 1995 (GATT: December 16, 1994). Djibouti's National Investment Promotion Agency (NIPA), made in 2001, promotes private sector investment, facilitates investment operations, and works to modernize the country's administrative system. The Ministry of Finance oversees NIPA and assists unfamiliar and domestic investors by disseminating data and streamlining administrative procedures.

As indicated by the UNCTAD World Investment Report 2020, FDI inflows to Djibouti came to $\$ 182$ million in 2019 , up from $\$ 170$ million in 2018 . The absolute stock unfamiliar direct investment was estimated at $\$ 1.8$ billion in 2018 and 2019. The service sector receives most 
of the FDI; the main investors are the Gulf States, Ethiopia, Yemen, China, the United States, France, Brazil, India and Turkey. As a COMESA member ready to attract more FDI, Djibouti specifically aims to build closer ties with the Gulf Cooperation Council and India (UNCTAD, 2020).

The main attractive feature for investment in the country is its strategic geographic location, which is located at the crossroads of sea routes between the Far East, the Persian Gulf, Africa and Europe, making deep port facilities and major railway's assets. Moreover, Djibouti has a stable, freely convertible currency pegged to the US dollar. Moreover, the government, which is implementing an ambitious infrastructure program, is offering substantial tax breaks to foreign investors.

Table 1. FDI in Djibouti

\begin{tabular}{lccc}
\hline FDI & 2017 & 2018 & 2019 \\
\hline FDI Inward Flow (million USD) & 165 & 170 & 182 \\
FDI Stock (million USD) & $1,403.4$ & $1,573.4$ & $1,755.4$ \\
Number of Greenfield Investments & 1.0 & 1.0 & 3.0 \\
Value of Greenfield Investments (million USD) & 10 & 186 & 181 \\
\hline
\end{tabular}

Source: UNCTAD - Latest available data

Note: Greenfield Investments are a form of FDI where a parent company starts a new venture in a foreign country by constructing new operational facilities from the ground up.

\subsection{Literature Review}

The existing empirical literature on FDI and EG has been estimated by estimating its effect on factors, such as GDP growth/efficiency or the determinants of FDI. An examination by Ridzuan (2017) found that it has a significant and positive impact on EG, as it reduces the problem of wage imbalance, and the information in the example is based on annual information covering the period 1970-2013. The long-term resilience shows that FDI inflows not only lead to expanded economic growth and environmental quality, but also to a country's wage imbalance, which may upset its central objective. In light of the results, the two stimulated more stable EG and reduced environmental corruption. This variable does not significantly affect payment terms in Singapore. Selamawit Berhe Woldekidan (2015) His analysis conducted that there is a positive and significant relationship between FDI and real GDP growth, a moderately positive association between export performance and FDI, and a negative and insignificant association between FDI and spillovers in Ethiopia. Adeleke Kunle M. \& Olowe S.O and Faces in Oladipo Oluwafolakemi (2014) Their findings revealed that 
economic growth is directly related to the inflow of foreign direct investment and it is also statistically significant at 5\% level which implies that a good performance of the economy is a positive signal for the inflow of foreign direct investment. This implies that foreign direct investment is an engine of economic growth. The results presented in this article show a negative relationship between FDI and EG. Woldekidan (2015) revealed a positive and a huge relationship between FDI and real GDP growth, a positive relationship between export performance and FDI, and a negative and non-material relationship between FDI relationship and the viral effects in Ethiopia. Since 1992, the current framework has made remarkable attempts to attract unfamiliar direct projects and encourage positive improvement effects. The current framework provided extensive attempts to enter into an uncommon straightforward adventure. Constructive consequences of transforming events. Berhane (2015) investigation of FDI in Ethiopia based on tests using the combined VAR approach during the period $1974 / 75$ to $2013 / 14 \mathrm{G}$ Based on his findings, in the long run, explanatory Factors such as infrastructure development, domestic market size, human capital, openness, and external commitment are seen as categorically and really huge while inflation is negatively and critically correlated measurably. In the short run, gross fixed capital formation and inflation become negatively correlated which are measurably critical while GDP is certainly correlated and really huge. While the remaining factors of commitment reform, openness, and human capital have a positive coefficient, they are immaterial in the short run. It is also seen that there is a two-way causal relationship between gross fixed capital formation and foreign direct investment. The explanatory factors of inflation, GDP, debt service, openness, and human capital are an uncommon cause of direct speculation but not the other way around. As a rule, importantly determinants of FDI are infrastructure practices, market size, macroeconomic security, and openness in the long run. Egypt has a huge positive impact on foreign direct investment. These points to the crucial role of growth in stimulating investment by both foreign and domestic investors. Zekarias 1 (2016) he analyzed the impact of FDI on EG in East Africa. Using 34-year panel data (1980-2013), dynamic GMM estimators were used after confirmation autocorrelation and model specification tests. Developing countries have attracted FDI while trying to reduce resource gaps, technological gap, and unemployment and trade deficits. The results confirm that FDI has marginally significant effect of FDI on EG, the conditional economic convergence rate of 5\%, significant exclusion of FDI domestic investment, interdependence of domestic investment and trade openness in the sub region. Thus, discover that FDI is a key driver of EG and a catalyst for conditional economic convergence in East Africa; Thus, the sub region needs to attract more FDI by improving investment environment, strengthen regional integration, develop human capital and basic infrastructure, and promote export-oriented investment. Multi Chanie (2017) found that the growth effects of domestic capital investment, international trade, and labor force growth rates are positive and statistically. And the structural dummy variable shows a marked improvement in FDI inflows and EG after 1991 in Ethiopia.

\section{Methodology}

The purpose of this study is to assess and analyze the impact of inward FDI on EG in Djibouti and identify the relationship and significance of the independent variables with the 


\section{Macrothink

dependent variable inward of FDI. Therefore, time serious study of the period from 1985 to 2019 G.C. Has been applied. It adopts a quantitative approach using ordinary least square regression model. The OLS method is selected due to its' commonly used by most previous researchers on this topic area and its capability to minimize bias on the analysis.

The historical data from 1985 to 2019 for (GDP growth) and independent variables (Foreign Direct Investment (FDI), Domestic Capital (GFCF), Trade Openness (TOP), and Human Development Index (HDI), consumer Prices Index (CPI)) of the research study were collected from Djibouti government offices like the Djibouti Investment Commission, Ministry of Finance and Economic Cooperation, and Statistical Agency. The World Bank and United Nations Conference for Trade and Development reports and publications that can be found from their websites also used as a data source.

\subsection{Establishment of Empirical Models}

\subsubsection{Model Specification and Estimation}

To investigate the impact of FDI on EG, the dependent variable is EG, and independent variables include FDI, Domestic Capital (GFCF), Trade Openness, Human Development Index, Consumer Price Index

$$
\mathrm{Y}=\mathrm{F}(\mathrm{FDI}, \mathrm{GFCF}, \mathrm{TOP}, \mathrm{HDI}, \mathrm{CPI})
$$

Where:

$\mathrm{Y}$ is a Goss Domestic Product, FDI is the FDI net inflows, the GFCF is Gross Fixed Capital Formation, TOP is the Trade Openness, HDI is the Human Development Index, CPI is the Consumer Price Index.

$$
\mathrm{LnGDP}=\beta 0+\beta 1 \mathrm{LnFDI}+\beta 2 \mathrm{LnGFCF}+\beta 3 \mathrm{LnTOP}+\beta 4 \mathrm{LnHDI}+\beta 5 \mathrm{LnCPI} \varepsilon
$$

Where LnGDP denotes Gross Domestic Product, LnFDI denotes, Ln GFCF denotes Domestic Capital, and LnTOP the Trade Openess, LnHDI denote Human Development Index, LnCPI denote Consumer Price Index.

$\beta 0=$ constant term

$\beta \mathrm{i}=$ Regression coefficients.

$$
\mathrm{I}=1,2,3,4,5
$$

$\varepsilon=$ the error term

\subsection{Measurement Data}

Table 2. Macroeconomic variables

LABEL DESCRIPTION SOURCES

Y Gross Domestic Product

WDI, 2018 
FDI FDI alludes to coordinate venture value streams in the revealing economy. It is the total of value capital, reinvestment

UNCTAD, of profit, and other capital. The direct investment is a classification of cross-out skirt speculation related to an occupant in one economy having control or a huge level of effect on the administration of an endeavor that is an inhabitant in another economy. Responsibility for percent or a greater amount of the standard offers of casting a ballot stock is the measure for deciding the presence of an immediate venture relationship.

Gross fixed capital formation (formerly a gross domestic fixed WDI, 2020

GFCF investment) incorporates land upgrades (wall, trenches, channels, etc.); plant, hardware, and gear buys; and the development of streets, railroads, and such, including schools, workplaces, medical clinics, private residences, and business and modern structures. As per the 1993 SNA, net acquisitions of assets are likewise thinking about capital formation

Trade openness refers to the inward and outward orientation of WDI, 2020

TOP economies to take or overlook the advantage of the opportunities to trade with other countries. The trade openness of economies can be indicated by the ratio of trade to the gross domestic product of the country. Most researchers argued that trade openness brings many economic benefits including technology transfer, knowledge and skill transfer, labor \& total factor productivity improvement, and EG.

HDI The HDI was made to underscore that individuals and their UNCTAD abilities ought to be a definitive rule for surveying the I, 2020 improvement of a country, not financial development alone. The HDI can likewise be utilized to address public arrangement decisions, requesting how two nations with a similar level from GNI per capita can wind up with various human advancement results. These differentiations can invigorate banter about government strategy needs.

The Human Improvement Record (HDI) is a synopsis proportion of normal accomplishment in key elements of human turn of events: a long and solid life, being educated and have a respectable way of life. The HDI is the mathematical mean of standardized records for every one of the three measurements. 
CPI The Consumer price index reflects changes in the expense for WDA, the normal purchaser obtaining a bushel of labor and products 2020 that might be fixed or changed at indicated spans, like yearly. The Laspeyres equation is for the most part utilized

Source: Author, 2019 (Compiled from WDI, UNCTAD).

\subsection{Results and Discussion}

Table 3. Regression results for Factors affecting GDP in Djibouti

Dependent variable: GDP

Independent variables: FDI, GFCF, TOP, HDI, CPI

Number of observations: 34

\begin{tabular}{lllll}
\hline Variable & Coefficient & Std. Error & T-Statistic & Prob \\
\hline FDI & -0.1089427 & 0.0357544 & -3.05 & 0.005 \\
GFCF & 0.0453542 & 0.0107183 & 4.23 & 0.000 \\
TOP & 0.322342 & 0.0538889 & 5.98 & 0.000 \\
HDI & 2.362967 & 0.5653789 & 4.18 & 0.000 \\
CPI & 0.048802 & 0.0403359 & 1.21 & 0.236 \\
Cons & 5.239286 & 0.4088841 & 12.81 & 0.000 \\
\hline
\end{tabular}

R-squared 0.96; Adj R-squared 0.95; Prob (F-statistic) value, 0.0000,

Source: own computation using Stata software.

After rejecting the results of the estimation of the OLS regression in the table above that the R-square showed that the independent variables explain about $96 \%$ of the changes in the EG (dependent variable). The adjusted R-Squared value of 95\% supports the fact that the model is nicely fitted and the Prob (F-statistic) value of 0.0000 indicates that the regression model is significant.

The $p$ value of FDI is 0.005 it shows significant value, but Coefficient value shows a negative 
relationship between FDI and Djibouti growth, which is -0.109 , The result is in line with the study of Bashir, Taqadus (2014), and Meskerem Demissie (2015).

Therefore, the relationship between Domestic Capital and Growth Domestic Product is positive as shown in the above table, the coefficient of Domestic Capital has a positive sign and statistically significant on GDP.

Whereas in our case found trade (a proxy for the economy's openness) positively associated with GDP growth and statistically significant impact on GDP.

The coefficient for the human development index is found to be significantly and positively related to EG in Djibouti; this is due to the availability of education and income levels in the Djiboutian economy. This means that a good level of the HDI is the contribution of FDI to growth because the HDI is one of the main pillars of Djibouti's socio-economic development policy, because of its central importance to the country's sustainable development. Proposing the HDI as one of the reasons for differential response to FDI at different income levels.

In our case consumer price index found positively associated with GDP growth, but statistically insignificant impact on GDP. The coefficient defined that a $1 \%$ increase in CPI volume would decrease the GDP by $0.048802 \%$.

This study explores the impact of FDI on economic growth (GDP), focusing on foreign direct investment, and human development index, and domestic capital, trade openness, and consumer price index in affecting the economic growth in Djibouti.

Previous studies have identified that FDI, labor force, and domestic capital, trade openness, may affect positively or negatively on GDP. The principal objectives of this study are to quantify the relative impact of those factors on GDP in the last three decades and explore if such impact changes over time For this reason, I utilized the OLS relapse model to accomplish the targets of the examination.

The aim of this study was to know how FDI affects EG in Djibouti. According to the findings, the results demonstrated that FDI and CPI have a limited effect on EG. While Domestic Capital and Human Development Index and Trade Openness has a positive effect on EG. These results indicate that in order to increase Djibouti's GDP, there is a need to improve FDI and CPI.

Specifically, in order to encourage EG, policymakers should encourage FDI, therefore, the considered view of the researcher, it has to make the required amendments to the investment law and remove any obstacle posed by the current law, it is most important to grant incentives, privileges, and facilities, and The government should work to improve infrastructure such as expanding roads in the rural areas and the expansion of electric power to the various regions of Djibouti and the development of the performance of electric power and work to find alternative sources of energy such as gas, solar and wind energy Considering that electricity is the most important elements of investment success. And involving the private sector in the creation of some of the infrastructure, and this method may help to attract foreign investment to contribute to infrastructure projects such as electricity. And the government of Djibouti 
should verify that the existing policies, regulations, and institutions are adequate, and consultations with all stakeholders. For further empirical studies, it will be interesting to study how FDI inflow contributes to economic development in Djibouti.

The government should also work on the establishment of industrial zones as considering one of the most important methods to attract local and foreign investments, that is, the presence of industrial zones with infrastructure will achieve a profitable and competitive return.

The rationale for investment in improvements in vocational education to attract foreign firms is strengthened by the likelihood that they will improve the business environment for indigenous firms as well. Since multinational corporations are often attracted to developing nations by the abundance of their cheap labor, the higher level of the labor force is a good indicator of the availability of skilled workers, which, along with cheap labor, can significantly boost the locational advantage of a host country and Djibouti's location is suitable.

Working to promote trade openness policy through bilateral and regional cooperation with countries and economic blocs, especially with countries and regional blocs which near' Djibouti, such as GAFTA and GCC, in addition to the need to work hard in order to achieve optimum utilization of the advantages resulting from applied of trade agreements with these countries and economic blocs. As well as to maximize the benefit of Djibouti's strategic location in the world, this would serve to reduce production costs and create new markets for exports thus contribute to achieving EG.

\section{References}

Abebe, S. M. (2015). Prevalence and associated factors of hypertension: a crossectional community based study in Northwest Ethiopia. PloS one, 10.4, e0125210. https://doi.org/10.1371/journal.pone.0125210

Berhe, S. (2015). Foreign direct investment and economic development in Ethiopia. Unpublished MA thesis at Copenhagen.

Demirsel, M. T., Adem, O., \& Mehmet, M. (2014). The effect of foreign direct investment on economic growth: the case of Turkey. Proceedings of International Academic Conferences. International Institute of Social and Economic Sciences.

Dinh, T. T. H., Vo, D. H., \& Nguyen, T. C. (2019). Foreign direct investment and economic growth in the short run and long run: Empirical evidence from developing countries. Journal of Risk and Financial Management, 12(4), 176. https://doi.org/10.3390/jrfm12040176

Hamed, Y. (2014). Groundwater evolution of the Continental Intercalaire aquifer of Southern Tunisia and a part of Southern Algeria: use of geochemical and isotopic indicators. Desalination and Water Treatment, 52, 1990-1996. https://doi.org/10.1080/19443994. 2013.806221

Harris, S. C. (2014). Investment climate statement. US Department of State.

Kennedy, K. (1994). The World Trade Organization: legal, economic and political analysis. 


\section{Macrothink}

International Research in Education

ISSN 2327-5499

2021, Vol. 9, No. 2

Mohamed, M. M., \& Isak, I. (2017). The impact of foreign direct investment on economic growth in Somalia. SSRG International Journal of Economics and Management Studies, 4(8). https://doi.org/10.14445/23939125/IJEMS-V4I8P105

Ogbonna, S. (2006). What Is Killing Newspapers in Lagos State: the Internet or Dwindling Economy?

Opeyemi, A. F. (2020). Impact of foreign direct investment and inflation on economic growth of five randomly selected Countries in Africa. Journal of Economics and International Finance, 12(2), 65-73. https://doi.org/10.5897/JEIF2020.1031

Osano, H. M., \& Hilario, L. (2016). Factors influencing access to finance by SMEs in Mozambique: case of SMEs in Maputo central business district. Journal of innovation and entrepreneurship, 5(1). https://doi.org/10.1186/s13731-016-0041-0

Ridzuan, A. R., Nor, A. I., \& Abdul, F. C. H. (2017). Does foreign direct investment successfully lead to sustainable development in Singapore? Economies, 5(3). https://doi.org/ 10.3390/economies5030029

Weldegebriel, T. (2018). The Contribution of Chinese Foreign Direct Investment on the Economic Growth of Ethiopia. Diss. st. mary's University.

Woldekidan, H. (2015). The role of foreign aid in reducing poverty: Time series evidence from Ethiopia. Journal of Economics and International Finance, 7(3), 59-71. https://doi.org/ 10.5897/JEIF2015.0646

Zekarias, S. M. (2016). The impact of foreign direct investment (FDI) on economic growth in Eastern Africa: Evidence from panel data analysis. Applied Economics and Finance, 3(1), 145-160. https://doi.org/10.11114/aef.v3i1.1317

Zones, Special Economic. United Nations Conference on Trade and Development (UNCTAD) World Investment Report (WIR).

\section{Copyright Disclaimer}

Copyright reserved by the authors.

This article is an open-access article distributed under the terms and conditions of the Creative Commons Attribution license (http://creativecommons.org/licenses/by/4.0/). 